\title{
EFEKTIFITAS EKSTRAK BUAH MENGKUDU (Morinda citrifolia) SEBAGAI PESTISIDA NABATI UNTUK PENGENDALIAN MENCIT (Mus musculus)
}

\author{
Agnes Verawati Putri ${ }^{1^{*}}$, Hajimi Hajimi ${ }^{2}$, Zainal Akhmad ${ }^{3}$ \\ 1,2,3 Politeknik Kesehatan Kemenkes Pontianak
}

\section{Artikel Info : \\ Received 12 Februari 2022 Accepted 27 Februari 2022 Available online 28 Februari 2022}

Editor: Prayudhy Yushananta

Keyword :

Mmice, Morinda citrifolia, extract, biopesticide

Kata Kunci :

Mencit, Morinda citrifolia, ekstrak, biopestisida

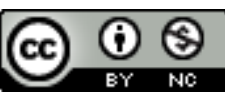

Ruwa Jurai: Jurnal Kesehatan Lingkungan is licensed under a Creative Commons Attribution-

NonCommercial 4.0 International License.

\begin{abstract}
A bstract
Pests often found in homes and harmful to humans are mice (Mus musculus). In addition to most ap and destroyer of building, Mus musculus also acts as a spreader of disease for humans. Controls carried out by the community are making traps or traps, rat poison, and smoking. In addition, there is a natural way, namely using noni fruit. This study aims to determine the effectiveness of noni fruit extract (Morinda citrifolia) as a vegetable pesticide against the control of mice (Mus musculus) and to determine differences in the effectiveness of noni fruit extract (Morinda citrifolia) at each dose variation of 35\%,40\%,45\%,50\%, and 55\%. This study uses a quasi-experimental design (quasi-experimental). The number of samples is 30 mice. Toxicity test on mice using the fixed-dose method. The statistical test used is the one-way Anova test. The results showed that there was an effect of the effectiveness of noni fruit extract (Morinda citrifolia) on the mortality of mice ( $p$-value $=0.000<0.05$ ), and at a concentration of $55 \%$ it was effective for killing mice (Mus musculus). However, at a concentration of $55 \%$, it cannot be said to be effective in killing mice (Mus musculus) because it can only kill $20 \%$ of mice.
\end{abstract}

Hama yang seringkali ditemukan didalam rumah dan merugikan bagi manusia adalah mencit (Mus musculus). Selain sebagai hama dan perusak bangunan, Mus musculus juga berperan sebagai penyebar penyakit bagi manusia. Pengendalian yang telah dilakukan oleh masyarakat adalah membuat jebakan atau perangkap, racun tikus, dan pengasapan. Selain itu terdapat cara alami yaitu menggunakan buah mengkudu. Penelitian ini bertujuan untuk mengetahui efektivitas ekstrak buah mengkudu (Morinda citrifolia) sebagai pestisida nabati terhadap pengendalian mencit (Mus musculus) dan untuk mengetahui perbedaan efektifitas ekstrak buah mengkudu (Morinda citrifolia) pada setiap variasi dosis yaitu 35\%,40\%, 45\%,50\%, dan 55\%. Penelitian ini menggunakan desain eksperimen semu (quasi experiment). Jumlah sampel 30 mencit. Uji toksisitas terhadap mencit menggunakan fixed dose methode. Uji statistik yang digunakan adalah uji one way Anova. Hasil penelitian mendapatkan adanya pengaruh efektifitas ekstrak buah mengkudu (Morinda citrifolia) terhadap kematian mencit ( $p$-value = $0,000<0,05$ ), akan tetapi pada kosentrasi 55\% belum dapat dikatakan efektif untuk membunuh hama mencit (Mus musculus) karena baru mampu membunuh 20\% mencit.

* Corresponding author: Agnes Verawati Putri

J. DR. Soedarso, Bangka Belitung Laut, Kec. Pontianak Tenggara, Kota Pontianak, Kalimantan Barat.

Email: agnesverawati18@gmail,com

\section{PENDAHULUAN}

Mus musculus (mencit) dikenal sebagai tikus pithi karena ukurannya yang kecil. Mencit merupakan hewan yang sering sekali hidup berdampingan dengan manusia (Rusmini \&
Handayani, 2011), sering ditemukan di dalam rumah yang kotor, di dalam lemari dan tempat tersembunyi lainnya (Marbawati \& Ismanto, 2011; Nasir et al., 2015). 
Selain sebagai hama dan perusak bangunan, keberadaannya juga berperan sebagai penyebar penyakit bagi manusia, sehingga harus dilakukan pengendalian. Pengendalian tikus yang biasa dilakukan masyarakat adalah memasang jebakan atau perangkap, racun tikus, dan pengasapan. Penggunaan perangkap memerlukan penanganan lanjutan terhadap tikus yang terperangkap, sehingga berisiko untuk lepas saat akan dilakukan penanganan lanjutan. Penggunaan racun tikus kimia berisiko terhadap kematian hewan non target (Meidinata, 2020). Oleh karena itu, perlu dikembangkan bahan alami yang mudah diperoleh sebagai alternatif pengendalian mencit. Salah satu bahan alami tersebut adalah buah mengkudu (Morinda citrifolia L.).

Buah mengkudu mengandung beberapa senyawa kimia metabolit sekunder diantaranya adalah antrakuinon, alkaloid (xeronin dan proxeronin), saponin, tanin, glikosida (Murdiati \& Adiwinatai, 2000; Sogandi \& Nilasari, 2019; Sogandi; Rabima, 2019). Senyawa alkaloid dan glikosida merupakan senyawa beracun yang menggangu sistem pencernaan. Penelitian bertujuan untuk mengetahui efektifitas ekstrak buah mengkudu terhadap kematian mencit.

\section{METODE}

Penelitian merupakan eksperimen semu (Quasy Experiment) untuk menganalisis efektifitas ekstrak buah mengkudu terhadap kematian mencit. Lima dosis ekstrak buah mengkudu (35\%, 40\%, 45\%, 50\%, 55\%) diujikan kepada 30 ekor mencit jantan usia tiga bulan, dengan kontrol sebagai pembanding. Penelitian dilakukan dengan lima kali ulangan.

Pembuatan ekstrak mengkudu dilakukan dengan cara mencuci buah mengkudu segar dan matang menggunakan air sumur. Selanjutnya dipotong-potong menjadi bagian yang kecil, dan dihancurkan menggunakan blender. Setelah disaring untuk memisahkan dengan cairan, dilakukan penimbangan untuk mendapatkan $75 \mathrm{~g}$ bahan ekstrak. Ekstraksi dilakukan dengan merendam bahan ekstrak dengan etanol 96\%, selama 2 × 24 jam. Selanjutnya disaring dan dipekatkan menggunakan vacuum rotary evaporator selama 24 jam, sehingga diperoleh larutan ekstrak yang pekat. Keseluruhan proses ekstraksi dilakukan di Laboratorium Teknologi Hasil Pertanian, Politeknik Negeri Pontianak.

Hewan coba yang digunakan adalah 30 ekor mencit jantan berusia 3 bulan, dengan berat 33-36 gram. Mencit dibagi dalam enam kelompok (5 untuk perlakuan dan 1 kelompok sebagai kontrol). Uji toksisitas dilakukan untuk mengetahui toksisitas oral akut terhadap bahan, dengan metode dosis tetap (fixed dose methode). Penggunaan metode ini dapat meminimalkan kebutuhan hewan uji (Teke \& Kuete, 2014).

Mencit dipuasakan selama empat jam, kemudian ditimbang. Selanjutnya masingmasing kelompok diberi ekstrak buah mengkudu dengan variasi dosis $0 \%, 35 \%, 40 \%, 45 \%, 50 \%$, dan 55\%. Pengamatan dilakukan setiap hasri selama 14 hari, untuk mengetahui dan mencatat kondisi mencit mulai dari tremor, diare, lemas, gerak mundur atau menggunakan perut, hingga kematian.

Data yang terkumpul selanjutnya dianalisis untuk mengetahui gambaran kematian mencit, serta perbedaan kematian mencit berdasarkan variasi dosis. Uji Sahpiro-Wilk dilakukan sebagai tahap awal analisis untuk mengetahui normalitas distibusi data. Selanjutnya dilakukan uji ANOVA One-way untuk mengetahui perbedaan kematian mencit berdasarkan variasi dosis. Sebagai pelengkap, dilakukan uji Tukey untuk mendapatkan perbedaan kematian mencit antar individu dosis. Keseluruhan analisis menggunakan aplikasi SPSS, pada tingkat kepercayaan $95 \%$.

\section{HASIL}

\section{a. Analisis univariat}

Hasil penelitian (Tabel 1) menunjukkan bahwa total kematian sebanyak 10 ekor, dengan rerata 1,6 ekor. Berdasarkan dosis, kematian tertingi terdapat pada dosis 55\%, menyebabkan kematian pada seluruh hewan uji (100\%). Penggunaan dua dosis awal (35\%, dan 40\%) tidak memberikan efek kematian pada mencit. Sementara, mortalitas pada dosis $45 \%$ dan $50 \%$, masing-masing sebesar $40 \%$ dan $60 \%$. Pada kelompok kontrol, setelah 48 jam pengamatan tidak menunjukkan kematian. 
Tabel 1. Kematian dan mortalitas mencit (Mus musculus) berdasarkan dosis

\begin{tabular}{llllllll}
\hline Dosis & \multicolumn{3}{l}{ Kematian/Ulangan } & \multicolumn{3}{c}{ Jumlah } & Mortalitas \\
\cline { 2 - 6 } & 1 & 2 & 3 & 4 & 5 & & \\
\hline Kontrol & 0 & 0 & 0 & 0 & 0 & 0 & 0 \\
$35 \%$ & 0 & 0 & 0 & 0 & 0 & 0 & 0 \\
$40 \%$ & 0 & 0 & 0 & 0 & 0 & 0 & 0 \\
$45 \%$ & 1 & 1 & 0 & 0 & 0 & 2 & 40 \\
$50 \%$ & 1 & 1 & 1 & 0 & 0 & 3 & 60 \\
$55 \%$ & 1 & 1 & 1 & 1 & 1 & 5 & 100 \\
\hline
\end{tabular}

b. Analisis bivariat

Uji normalitas dilakukan untuk mengetahui normalitas distribusi data sebagai syarat dilakukannya uji one way Anova. Hasil uji normalitas dengan Shapiro-Wilk (Tabel 2) diketahui bahwa data terdistribusi normal ( $p$ value $=0,131)$, sehingga analisis dapat dilanjutkan dengan Anova One-Way.

Tabel 2. Uji normalitas data

\begin{tabular}{lllll}
\hline Variabel & Statistic & Df & P & Kesimpulan \\
\hline Jumlah mencit yang mati & 0,840 & 6 & 0,131 & Distribusi data normal \\
\hline
\end{tabular}

Uji ANOVA dilakukan untuk mengetahui perbedaan jumlah kematian berdasarkan dosis perlakuan. Hasil analisis (Tabel 3) mendapatkan perbedaan secara signifikan kematian mencit berdasarkan variasi dosis ( $p$-value $<0,05)$. Hasil ini menjelaskan bahwa ekstrak buah mengkudu mampu memberikan efek kematian terhadap mencit.
Berdasarkan hasil uji Tukey (Tabel 4), diketahui bahwa perbedaan kematian mencit antara dosis $55 \%$ dengan $35 \%$ ( $p$-value $=0,001$ ), dan $55 \%$ dengan $40 \%$ ( $p$-value $=0,001)$. Sisanya tidak menunjukkan perbedaan yang signifikan ( $p$-value $>0,005$ ).

Tabel 3. Uji ANOVA

\begin{tabular}{llll}
\hline Variabel & $\mathrm{df}$ & $\mathrm{F}$ & Probabilitas \\
\hline Antar kelompok perlakuan (between groups) & 5 & & \\
Dalam kelompok perlakuan (within groups) & 24 & 8,533 & 0,000 \\
Total & 29 & & \\
\hline
\end{tabular}

Tabel 4. Uji Tukey

\begin{tabular}{llllll}
\hline Dosis & 35 & 40 & 45 & 50 & 55 \\
\hline 35 & - & 1,000 & 0,371 & 0,061 & 0,001 \\
40 & 1,000 & - & 0,371 & 0,061 & 0,001 \\
45 & 0,371 & 0,371 & - & 0,913 & 0,061 \\
50 & 0,061 & 0,061 & 0,913 & - & 0,913 \\
55 & 0,001 & 0,001 & 0,061 & 0,913 & - \\
\hline
\end{tabular}

\section{PEMBAHASAN}

Hasil penelitian mendapatkan bahwa dosis 55\% memberikan efek pada kematian total mencit. Pada dosis $45 \%$ dan 50\%, mortalitas masing-masing sebesar $40 \%$ dan $60 \%$. Sedangkan penggunaan dosis $35 \%$, dan $40 \%$, tidak memberikan efek kematian setelah 48 jam pengamatan. Sementara, pada kelompok kontrol 
tidak ditemukan kematian. Hasil ini menunjukkan semakin tinggi dosis, maka semakin tinggi pula tingkat kematian mencit.

Kematian mencit karena hilangnya nafsu makan setelah mengkonsumsi ekstrak mengkudu. Akibatnya, mencit menjadi lemah, tremor, diare dan mati. Buah mengkudu mengandung senyawa alkaloid dan glikosida yang bersifat racun, sehingga dapat digunakan sebagai pestisida alami (Murdiati \& Adiwinatai, 2000; Sogandi \& Nilasari, 2019; Sogandi; Rabima, 2019). Menurut Rahmawasiah, dkk (2019), nafsu makan tikus lebih tinggi pada kelompok kontrol dibanding dengan kelompok perlakuan, karena senyawa dalam mengkudu mampu mengganggu proses pencernaan tikus.

Hasil analisis statistik dengan ANOVA mendapatkan perbedaan kematian mencit yang signifikan, berdasarkan variasi dosis ( $p$ value $<0,05)$. Perbedaan kematian mencit antara dosis $55 \%$ dengan $35 \%$ ( $p$-value $=0,001)$, dan $55 \%$ dengan $40 \%$ ( $p$-value $=0,001)$. Pemberian ekstrak buah mengkudu secara oral, menyebabkan zat aktif dalam ekstrak terabsorpsi dalam saluran pencernaan, dan mengalami proses distribusi dan metabolisme. Produk metabolisme yang bersifat toksik bekerja sebagai inhibitor enzim untuk tahap metabolisme selanjutnya. Reaksi antara zat aktif dengan reseptor dalam organ efektor menyebabkan timbulnya gejala keracunan (Jumain et al., 2018; Mustapa et al., 2015; Nonci et al., 2014).

Keterbatasan penelitian ini adalah: 1) jumlah hewan uji setiap perlakuan hanya satu ekor pada setiap blok perlakuan, sehingga tidak diketahui variasi setiap blok; 2) hewan uji diperoleh dari lingkungan, sehingga kualitasnya bervariasi; 3 ) pengamatan dilakukan secara visual, belum disertai dengan pemeriksaan organ maupun clinic laboratories. Namun demikian, penelitian telah membuktikan kemampuan ekstrak buah mengkudu untuk membunuh mencit. Sehingga dapat digunakan sebagai alternatif pengendalian mencit secara murah dan mudah. Diperlukan penelitian lebih lanjut untuk mengetahui efek variasi pelarut dan metode ekstraksi terhadap kandungan bahan aktif (alkaloid dan glikosida), serta eksplorasi tumbuhan lokal sebagai bahan baku pestisida alami.

\section{SIMPULAN}

Hasil penelitian mendapatkan kematian total mencit pada dosis 55\%. Secara statistik, kematian mencit secara signifikan berbeda menurut variasi dosis ekstrak. Perbedaan mortalitas pada dosis 55\% dengan 30\%, dan $55 \%$ dengan $40 \%$. Penelitian telah membuktikan bahwa ekstrak buah mengkudu mampu memberikan efek kematian, sehingga dapat dijadikan alternatif dalam pengendalian mencit.

\section{DAFTAR PUSTAKA}

Jumain, J., Syahruni, S., \& Farid, F. (2018). Uji Toksisitas Akut dan LD50 Ekstrak Etanol Daun Kirinyuh (Euphatorium odoratum Linn) pada Mencit (Mus musculus). Media Farmasi, 14(1), 28. https://doi.org/10.32382/mf.v14i1.82

Marbawati \& Ismanto. (2011). Identifikasi Tikus (Hasil Pelatihan Di Laboratorium Mamalia Lembaga Ilmu Pengetahuan Indonesia, Jakarta). Balai Litbang P2B2 Banjarnegara. Vol. 7, No. 02, Des 2011: 46-48. Balaba, 7(02), 4648.

Meidinata, N. (2020). Sesak Napas hingga Kematian, Ini Bahaya Racun Tikus Bila Dikonsumsi Manusia. Solopos.com. https://www.solopos.com/sesak-napashingga-kematian-ini-bahaya-racun-tikus-biladikonsumsi-manusia-1056513\#: :text=Jika racun tikus dicampur dengan,sel darah putih\%2C dan kematian.

Murdiati, T. B., \& Adiwinatai, G. (2000). Penelusuran Senyawa Aktif dari Buah Mengkudu (Morinda citrifolia) dengan Aktifitas Antelmintik terhadap Haemonchus Contortus. Balai Penelitian Veteriner, 1992, 5.

Mustapa, M. A., Tuloli, T. S., \& Mooduto, A. M. (2015). Uji Toksisitas Akut yang Diukur Dengan penentuan LD50 Ektrak etanol Bunga Cengkeh (Syzygium aromaticum L.) Terhadap Mencit ( Mus musculus) Menggunakan Metode Thompson-Weil.

Nasir, M., Hastuti, L., \& Rasnovi, S. (2015). Distribusi Jenis Mamalia Kecil Famili Muridae pada Tiga Tipe habitat di Kecamatan KUta Cot Glie Kabupaten Aceh Besar. Jurnal Prosiding Seminar Nasional Biotik, 1(1), 239-244.

Nonci, F. Y., Rusdi, M., \& Mohan, I. Z. F. La. (2014). Uji Toksisitas Akut Ekstrak Etanol Klika Jambu 
Mede (Anacardium occidentale l.) Pada Mencit Jantan (Mus musculus). Universitas Islam Negeri Alauddin Makassar.

Rahmawasiah, Hairuddin, R., \& Jalil, A. (2019). Uji Efektifitas Buah Mengkudu (Morinda citrifolia L.) Sebagai Pestisida Nabati terhadap Perilaku Makan Tikus Hama (Rattus argetiventer). Journal of Chemical Information and Modeling, 53(9), 1689-1699.

Rusmini, R., \& Handayani, S. (2011). Bahaya Leptospirosis (penyakit kencing tikus) \& cara pencegahanya. Gosyen Publishing, Yogyakarta.

Sogandi, S., \& Nilasari, P. (2019). Identifikasi

Senyawa Aktif Ekstrak Buah Mengkudu
(Morinda citrifolia L.) dan Potensinya sebagai Inhibitor Karies Gigi. Jurnal Kefarmasian Indonesia, 9(2), 73-81. https://doi.org/10.22435/jki.v9i2.1289

Sogandi; Rabima. (2019). Jurnal Kimia Sains dan Aplikasi Identifikasi Senyawa Aktif Ekstrak Buah Mengkudu ( Morinda. Jurnal Kimia Sains Dan Aplikasi, 22(5), 206-212.

Teke, G. N., \& Kuete, V. (2014). Acute and Subacute Toxicities of African Medicinal Plants. In Toxicological Survey of Africn Medicinal Plants. https://doi.org/https://doi.org/10.1016/B9780-12-800018-2.00005-4 